\title{
Three new species of the genus Trechus Clairville, 1806 from Sichuan (Coleoptera: Carabidae: Trechini)
}

\section{Три новых вида Trechus Clairville, 1806 из провинции Сычуань (Coleoptera: Carabidae: Trechini)}

\author{
Igor A. Belousov, Ilya I. Kabak \\ И.А. Белоусов, И.И. Кабак
}

\begin{abstract}
All-Russian Institute of Plant Protection, Podbelskogo 3, St. Petersburg - Pushkin 196608, Russia. E-mail: ibelous@yandex.ru; ilkabak@yandex.ru

Всероссийский институт защиты растений, шоссе Подбельского 3, 196608, Санкт-Петербург-Пушкин, Россия.
\end{abstract}

\author{
KEY WORDS: Trechini, taxonomy, China, Sichuan. \\ КЛЮЧЕВЫЕ СЛОВА: Trechini, таксономия, Китай, Сычуань.
}

ABSTRACT. 3 new species of ground beetles of the genus Trechus Clairville, 1806 are described from the basin of the Zagunao River (China, Sichuan Province): $T$. xiongmao sp.n. from the mountains located west of the village of Shangmeng, NW of Lixian City, T. comma sp.n. and T. sharovae sp. n., both from the upper valley of the Sanchagou River located north of the Tonghua Township, between Lixian and Wenchuan cities. Two species groups are defined to incorporate the new species: $T$. sharovae sp.n. belongs to the validicollis species group while the two other species - to the xiei species group. Photographs of habitus are provided and the median lobe of aedeagus is illustrated for each species.

РЕЗЮМЕ. Описано три новых вида жужелиц рода Trechus Clairville, 1806 из бассейна р. Цзагунао (Китай, провинция Сычуань): T. xiongmao sp.n. из гор, расположенных к западу от пос. Шанмэн (C3 города Лисянь), T. сотma sp.n. и T. sharovae sp. n., оба из верхнего течения р. Саньчагоу к северу от пос. Тунхуа (между городами Лисянь и Вэньчуань). Даны определения двух групп видов, в которые включены новые виды: T. sharovae sp.n. относится к группе видов validicollis, два других вида - к группе видов xiei. По каждому виду даны фотографии габитуса и рисунки медиальной доли эдеагуса.

\section{Introduction}

The present paper continues the authors' studies on Chinese members of the genus Trechus Clairville, 1806 from China [Belousov, Kabak, 1996, 2000, 2001, 2019a, b, 2020]. Species of the genus occur mostly in high altitude areas of the country and are particularly abun- dant in Xinjiang, Xizang (Tibet), Qinghai, Gansu, Sichuan, Shaanxi, and Yunnan provinces. Despite of numerous publications in recent thirty years [e.g., Deuve, 1992, 2004, 2009; Deuve, Quéinnec, 1993; Sciaky, Pavesi, 1995; Schmidt, 2009; Deuve et al., 2015], the Trechus fauna of these provinces remains poorly known. During last twenty years, the authors of this paper collected many Trechus species in these areas. Their taxonomic treatment shows that the number of new, undescribed taxa significantly outweighs the number of known species. Most of these new species will be described in the taxonomic papers, each dealing with one or a few species groups. In the present article, three well-isolated Trechus species that do not require exhausting comparisons with related taxa are described new to science. Two species groups are defined: the validicollis species group to incorporate $T$. sharovae sp. n., and the xiei species group to include T. xiongmao sp.n. and T. comma sp.n.

\section{Material and Methods}

The study is based on the examination of several hundred Trechus specimens of the validicollis and xiei species groups which were mostly collected by the authors in recent years.

Specimens were examined and measured with an MBS-10 stereomicroscope and an ocular micrometer. The male genitalia were extracted and prepared using a conventional technique and preserved in euparal on pieces of film and in microtubes with glycerin pinned under the specimens.

Photographs of beetles were taken with a Canon 5DS DSLR digital camera, using stacking and subse-

How to cite this article: Belousov I.A., Kabak I.I. 2021. hree new species of the genus Trechus Clairville, 1806 from Sichuan (Coleoptera: Carabidae: Trechini) // Russian Entomol. J. Vol.30. No.4. P.401-412. doi: 10.15298/ rusentj.30.4.04 
quently processed with Zerene stacker software version 1.04 (http://zerenesystems.com/stacker).

Twenty specimens, if available, were measured for each geographical locality. Measurements used here are the same as in our previous articles [e.g., Belousov, Kabak, 2000, 2003, 2014, 2019b]. The body length was measured without mandibles, from the anterior margin of labrum to the elytral apex, the width of the pronotal base at the narrowest point, i.e., without hind angles if these are protruding. The position of the anterior setiferous pore of the pronotum, the discal, preapical and umbilicate pores of the elytra are given as percentages of the length of the pronotum and elytra correspondingly. The latter were measured from the anterior termination of the lateral border to the apex of the longest elytron. Average values are given in parentheses. All morphometric characters are summarized in Table 1.

The nonparametric Mann-Whitney U-test and the parametric Student's $t$-test were applied to study the sexual dimorphism, infraspecific variability and to estimate differences between species in morphometric characters.

The number of specimens studied is followed by the number of genitalia preparations given in parentheses.

The figures of the male genitalia are arranged in plates in a way to facilitate comparisons of closely related species and the species descriptions follow this order.

Abbreviations used in the paper are as follows: AL length of antennae; AS - apical striole; $\mathrm{BH}$ - height of body, i.e. maximum thickness of abdomen with elytra in lateral view; D1, D2 - distance from the anterior end of the lateral border of elytron to the level of the anterior and posterior discal setiferous pores respectively; DP — the same for the preapical pore; EL - length of elytra; EW — width of elytra; HW - width of head; L2 — length of antennomere 2; L3 - length of antennomere 3; PA width of pronotum at anterior margin; $\mathrm{PB}$ - width of pronotum at base; PL - length of pronotum; PSa distance from the anterior margin of the pronotum to the level of the anterior lateral seta; PW — width of pronotum; TaL — length of hind tarsus; TiL — length of hind tibia; TL - length of tempora; U1-8 - distance from the anterior end of the lateral border of elytron to the level of the corresponding umbilicate pore; W3 — width of antennomere 3; YL - length of eye.

For description of striation on the apical slope of elytra we use the designation as follows " $((2 \times 3) \times 4)$ $((5 \times 6) \times 7) x A S "$ where the sign " $x$ " means the connection of the corresponding striae and braces indicate the order in which striae are joined in direction to the apex of elytra. In other words, " $(5 \times 6) \times 7$ " means that stria 5 firstly joins stria 6 and the resulting stria is connected with stria 7 closer to the elytral apex.

All figures, unless noted otherwise, refer to the paratypes from the type locality.

The coordinates of the collecting sites for the species described in the present paper are determined using Google Earth software some years after expeditions and are missing in the original labels. To prevent misunderstanding, these are given in square brackets in contrast to the label text which is placed inside quotation marks. In the case when two pairs of coordinates are given, it means that, at least, a few specimens of the species were found between these coordinates.

All the holotypes and a proportion of the paratypes of the new species are housed in the collection of the Zoological Institute of the Russian Academy of Sciences (ZIN, St. Petersburg, Boris Kataev). Other paratypes are distributed among the following institutions and working collections: BMNH - British Natural History Museum, London, Great Britain, Maxwell Barclay; IZAS Institute of Zoology, Chinese Academy of Science, Beijing, China, Hongbin Liang; MPU - Moscow State Pedagogical University, Moscow, Russia, Kirill Makarov; NME - Naturkundemuseum, Erfurt, Germany, Matthias Hartmann; SMNS — Staatliches Museum für Naturkunde, Stuttgart, Germany, Arnaud Faille; ZSM Zoologische Staatssammlung, München, Germany, Michael Balke; CAG — working collection of Arthur Gitzen, Neuhofen, Germany; CAK — working collection of Alexander Koval, St. Petersburg, Russia; CBK working collection of Igor Belousov and Ilya Kabak, St. Petersburg, Russia; CDW - working collection of David W. Wrase, Gusow-Platkow (part of Zoologische Staatssammlung München), Germany; CJS - working collection of Joachim Schmidt, Admannshagen, Germany; CVZ - working collection of Vladimir Zieris, Pardubice, Czech Republic.

\section{Taxonomy}

\section{Trechus Clairville, 1806 \\ The $x$ iei-species group}

The group includes species from northern and central Sichuan. It can be characterized by the following set of character states: medium to small body size, habitus robust and convex, color pale testaceous to brownish, occasionally with blackish elytra; eyes medium to rather small, pronotum with base clearly oblique on sides and small hind angles. The most important diagnostic feature of the group is the structure of the male genitalia: the median lobe small to medium, with a short comma-like endophallus armature pointed apically. The group is named after Trechus xiei Deuve, 1992 from Wolong ("col de Balangshan"), Sichuan [Deuve, 1992], the first described member of the group. Species of the group occur mostly in the upper forest belt, often near timber-line, rarely - in the lower alpine zone, but, to date, no species appears to be exclusive for high altitude alpine meadows.

\section{Trechus xiongmao sp.n. Figs 1-4.}

MATERIAL. Holotype $\sigma^{7}$, "China, NW Sichuan, NW of Lixian, $9 \mathrm{~km} \mathrm{~W}$ of Shangmeng, scree above timber-line 3600-3800 m, 23.07.2002, Belousov I. \& Kabak I. leg." $\left[31^{\circ} 40^{\prime} 30^{\prime \prime} \mathrm{N} / 103^{\circ}\right.$ 02'25"E]. Paratypes: 14(7) $\mathrm{O}^{7} \mathrm{O}^{7}$, 11 우, collected with holotype (BMNH, IZAS, NME, MPU, SMNS, ZSM, CAG, CAK, CBK); $1 \mathrm{fo}$ ", "China, NW Sichuan, NW of Lixian, $10 \mathrm{~km}$ WNW of Shangmeng, forest $3350 \mathrm{~m}, 22.07 .2002$, Belousov I. \& Kabak I. leg."

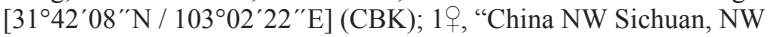
of Lixian, $10 \mathrm{~km} \mathrm{WSW}$ of Shangmeng, alp., scree $3850-4000 \mathrm{~m}$, 25.07.2002, Belousov I. \& Kabak I. leg." [31 $39^{\prime} 40^{\prime \prime} \mathrm{N}$ / $\left.103^{\circ} 01^{\prime} 50^{\prime \prime} \mathrm{E}\right]$ (CBK). 


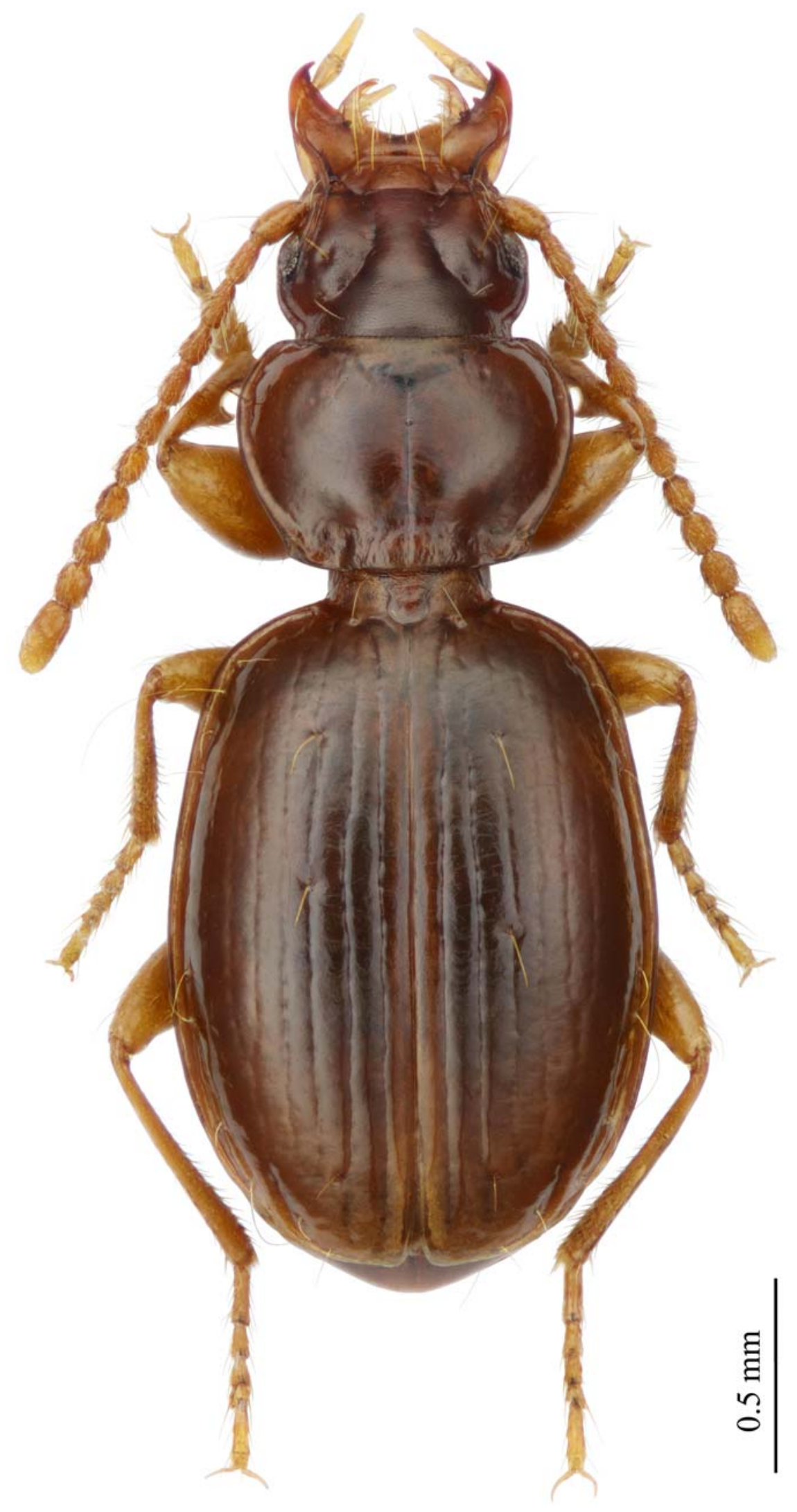

Fig. 1. Habitus of Trechus xiongmao sp. n., $\bigcirc^{7}$, paratype.

Рис. 1. Общий вид Trechus xiongmao sp. n., о , паратип. 
DESCRIPTION. Small-sized species with body length usually less than $3 \mathrm{~mm}$. Body broad ovate, constricted at pronotal base, very convex. Appendages not long, legs stout (Fig. 1). Upper side usually dark brownish, suture, margins of elytra, and occasionally disc of pronotum pale reddish; more rarely whole dorsum amber brownish. Head before clypeal suture much paler than behind, boundary not sharp. Legs yellowish. Antennae concolorous, reddish yellow.

Microsculpture well developed over entire surface of both head and pronotum, though becoming shallower on disc of the latter, consisting of isodiametric meshes on disc of head, slightly transverse meshes on anterior portion of pronotum, and markedly transverse meshes on its posterior portion; microsculpture of elytra shallow, consisting of transverse anastomosing lines, surface of elytra with iridescent luster. All upper side micropunctured.

Head of medium size, eyes rather small and flat, tempora long and convex, with a few very short hairs. Frontal furrows regularly impressed, subangulate and approaching one another before middle; frons convex. Supraorbital setae located in lines, distinctly convergent anteriad, posterior seta far behind posterior margin of eye. Pores of both anterior and posterior setae foveolate, though posterior pore less deeply impressed. Mandibles stout, evenly curved. Tooth on right mandible tridentate, its shape rather variable but distal denticle always most prominent. Anterior margin of labrum concave.

Pronotum markedly transverse, convex, with maximum width in apical third, clearly contracted to base, approximately as wide at base as at apex. Its sides broadly arcuate in anterior part, then nearly straight and convergent, with very shallow or no sinuation before hind angles, latter obtuse, blunt, or sharp at apex, always distinct. Posterior margin straight or slightly convex medially, obliquely truncate laterally; anterior margin straight. Anterior angles marked but not salient. Lateral margins bordered and reflexed, lateral groove of average width, clearly expanded posteriorly. Prebasal transverse impression shallow, vaguely delimited, angularly curved in basal foveae, the latter are of average size. Apical transverse impression continuous, well engraved laterally, becoming shallower or even interrupted medially. Discal foveae missing or slightly impressed. Anterior marginal seta placed in about anterior third of pronotum, posterior seta - in hind angle. Basal surface of pronotum distinctly rugose; wrinkles becoming sharper near basal margin. Median line regular, slightly impressed, becoming deeper near prebasal impression.

Elytra broad oval, with arcuate sides, widest just after their middle. Humeri broadly rounded, prehumeral margin evenly arcuate, posthumeral sinuation indistinct. Elytral apex broadly rounded, nearly truncate, with a distinct preapical sinuation. Elytral striae rather deep and regular, nearly entire, even stria 7 visible in its middle portion. Intervals 3-4 rather convex, interval 2 about 1.5 times as wide as interval 1 in their apical third. All elytral striae finely punctured and slightly undulate. Stria 2 surpassing level of preapical pore, occasionally redoubled behind it, often without clear connection with stria 3 , latter joining stria 4 at level slightly behind anterior end of apical striole. Striae 5 and 6 joining each other slightly behind median group of umbilicate series or near that level; stria 7 without clear connection with any of other striae. Parascutellar striole and parascutellar seta present. Apical recurrent striole of average length, rather deep and straight, usually not reaching level of mid-distance between umbilicate pores 7 and 8 , joining merged stria $(5 \times 6)$ anteriorly. The dominant pattern of striation on apical slope of elytra may be described as follows: $((5 \times 6) \times A S)(3 \times 4)(2 \times 3)$ where each next conjunction ' $x$ ' is located closer to the elytral apex. Apical triangle (consisting of three pores on the apical slope of each elytron, including the preapical pore) usually slightly elongate, its inner side convergent with suture anteriorly. Preapical pore set at level clearly behind anterior termination of apical striole. Angulo-apical pore usually placed closer to exterior pore than to elytral suture. Lateral margins bordered and markedly reflexed.

Protibiae flattened and grooved on exterior surface; two basal segments of male protarsi dilated, markedly transverse.

Median lobe of aedeagus of average size, subcylindrical, sharply curved at basal third, with straight ventral margin and small apical dilation, apical lamella rather large, its sides gradually narrowed toward apex in lateral view (Figs 2, 4); and nearly parallel sided in dorsal view (Fig. 3). Sagittal aileron of medium size. Parameres of average length, straight in apical half, left one clearly longer, with a well-developed ventral apophysis; each paramere bearing 4 apical setae (Fig. 2 ). Endophallus armature is similar to that of $T$. gansuensis Deuve et Quéinnec, 1993 and related taxa, consisting of poorly defined sclerite, S-shaped in dorsal view, and one small scaly area located near left wall of the median lobe.

SEXUAL DIMORPHISM. Males differ in smaller head (PW/HW, on average, $1.32 \mathrm{~mm}$ vs. $1.29 \mathrm{~mm}$ in females, $\mathrm{p} \leq 0.01$ ), larger eyes (YL/TL, on average, 1.34 vs. 1.25 in females, $\mathrm{p} \leq 0.05$ ), and less transverse pronotum (PW/PL, on average, 1.41 vs. 1.44 in females, $p \leq 0.05$ ).

COMPARATIVE NOTES. T. xiongmao sp.n. is similar to T. xiei Deuve, 1992. However, it differs from this species in having larger body size (2.72-3.15, on average, 2.93 vs. 2.44-3.04, on average, 2.81 in T. xiei), darker color of upper side, broader base of pronotum and longer antennae (see Table 2) and particularly it may be distinguished by the shape of the median lobe, which is much bigger, with endophallus armature more heavily sclerotized, and its distal portion more markedly curved (Figs 2-4).

On the other hand, T. xiongmao sp.n. is similar to $T$. gansuensis Deuve \& Quéinnec, 1993 described from Gansu: "120 km au sud-ouest de Lanzhou, Ponggartang" [Deuve, Quéinnec, 1993] but differs in having more broadly ovate habitus, smaller eyes (their diameter only slightly exceeding length of both tempora and antennomere 3 ), longer antennae, more transverse pronotum (PW/PL 1.43 vs. 1.36, PW/HW 1.30 vs. 1.26 in T. gansuensis), wider and more convex elytra (EL/BH 2.24 vs. 2.37 ) and larger pronotum (EL/PL 2.75 vs. 2.80 ); the preapical pore removed farther from the apex of elytra, umbilicate pores 1-4 removed from umbilicate pore 5 and placed closer to the base of elytra (the significance of differences in the above morphometric characters was based on the $t$-criterion, species comparison on the Mann-Whitney criterion is shown in Table 2). Male genitalia of T. xiongmao sp.n. are similar to those of $T$. gansuensis, but the new species can be readily distinguished by the endophallus armature more developed and by the apex of the median lobe distinctly attenuated downward in lateral view

DISTRIBUTION. The species is known only from the type locality, situated in the upper valley of a small river located west of the village of Shangmeng in the upper basin of the Mengdonggou River, NW of Lixian Town, Li County, Sichuan.

BIONOMICS. The species occurs in a wide belt of altitudes in both the alpine and upper forest zones (though much more common in the latter) at elevations from 3350 to $4000 \mathrm{~m}$. Most specimens were sifted from the forest litter in rather humid habitats.

DERIVATIO NOMINIS. The species epithet refers to the Chinese name of giant panda occurring in the same area. 


\section{Trechus comma $\mathbf{s p .} \mathbf{n}$.}

Figs 5-8.

MATERIAL. Holotype $\sigma^{7}$, "China, NW Sichuan, NE of Lixian, $\mathrm{N}$ Tonghua, basin of river near Pingshitou, $\mathrm{S}$ of Shibanpengzi, H 3900 m, 22.08.2002, Belousov I. \& Kabak I. leg." [31 ${ }^{\circ} 44^{\prime} 41^{\prime \prime N}$

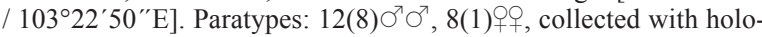
type (IZAS, NME, MPU, SMNS, ZSM, CAG, CBK, CJS); 13(4) $\mathrm{O}^{7} \mathrm{O}^{7}$, 6(1)우, "China, NW Sichuan, NE of Lixian, N Tonghua, basin of river near Pingshitou, S of Shibanpengzi, H 3600-3900 m, 20.08.2002, Belousov I. \& Kabak I. leg." [31 $44^{\prime} 30^{\prime \prime} \mathrm{N} / 103^{\circ} 22^{\prime} 50^{\prime \prime} \mathrm{E}-31^{\circ}$ $\left.44^{\prime} 41^{\prime \prime} \mathrm{N} / 103^{\circ} 22^{\prime} 50^{\prime \prime} \mathrm{E}\right]$ (BMNH, CAK, CVZ, CBK).

DESCRIPTION. Body ovate, markedly constricted at pronotal base, convex (Fig. 8). Appendages not long, legs stout, especially femora in males. Upper side reddish brown, often with darker blackish disc of elytra; the suture, margins of elytra and occasionally head and disc of pronotum paler, reddish. Legs and antennae uniformly yellowish. Head before clypeal suture reddish brown.

Microsculpture well developed on head and pronotum, though becoming shallower on disc of the latter, consisting of isodiametric meshes on median portion of head, more or less uniform transverse meshes on pronotum, and transverse shallow anastomosing lines on elytra, surface of elytra with iridescent luster. All upper side distinctly micropunctured.
Head of medium size, eyes rather small and flat, tempora long and convex, scarcely pubescent. Frontal furrows regularly impressed, subangulate, approaching one another in middle; frons convex. Supraorbital setae located in lines, slightly convergent anteriad, posterior seta far behind posterior margin of eye. Pore of anterior supraorbital seta markedly foveolate that of posterior seta slightly so. Mandibles stout, evenly curved. Tooth on right mandible tridentate, its shape rather variable, distal and proximal denticles always most prominent, with deepest notch between median and distal denticles. Labrum with anterior margin deeply concave.

Pronotum transverse, subconvex, with maximum width clearly before middle, markedly contracted at base. Its sides evenly and broadly arcuate, barely sinuate before hind angles, latter rather small but distinct, subrectangular. Posterior margin straight medially, obliquely truncate laterally; anterior margin straight. Anterior angles marked but not salient. Lateral margins narrowly bordered and slightly reflexed, lateral groove of average width, slightly expanded posteriorly. Prebasal transverse impression shallow, vaguely delimited, angularly curved in basal foveae, the latter rather small and shallow. Apical transverse impression irregular, occasionally interrupted medially. Discal foveae missing or slightly impressed. Anterior marginal seta placed in about anterior third of pronotum, posterior seta in hind angle. Base of

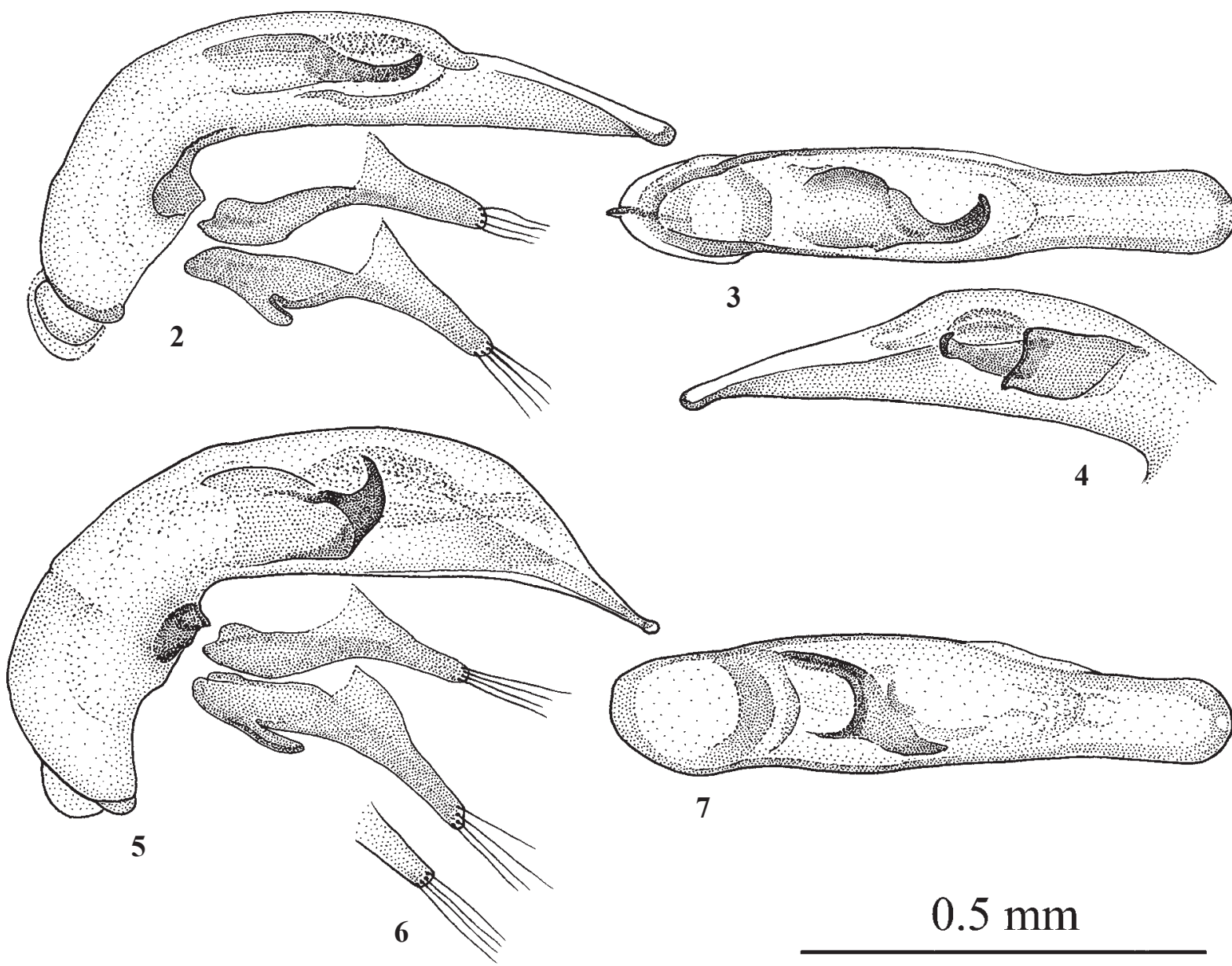

Figs 2-7. Male genitalia of Trechus spp. n.: 2-4 T. xiongmao sp. n., paratype; 5-7 - T. comma $\mathbf{s p .} \mathbf{n}$., paratype; 2, 5 - lateral view; 3,7 - dorsal view; 4 - distal portion, right lateral view; 6 - right paramere, apex.

Рис. 2-7. Гениталии самцов новых видов рода Trechus: 2-4 - T. xiongmao sp. n., паратип; 5-7 - T. сотта sp. n., паратип; 2, 5 - сбоку; 3, 7 - сверху; 4 - дистальная часть, справа; 6 - вершина правой парамеры. 


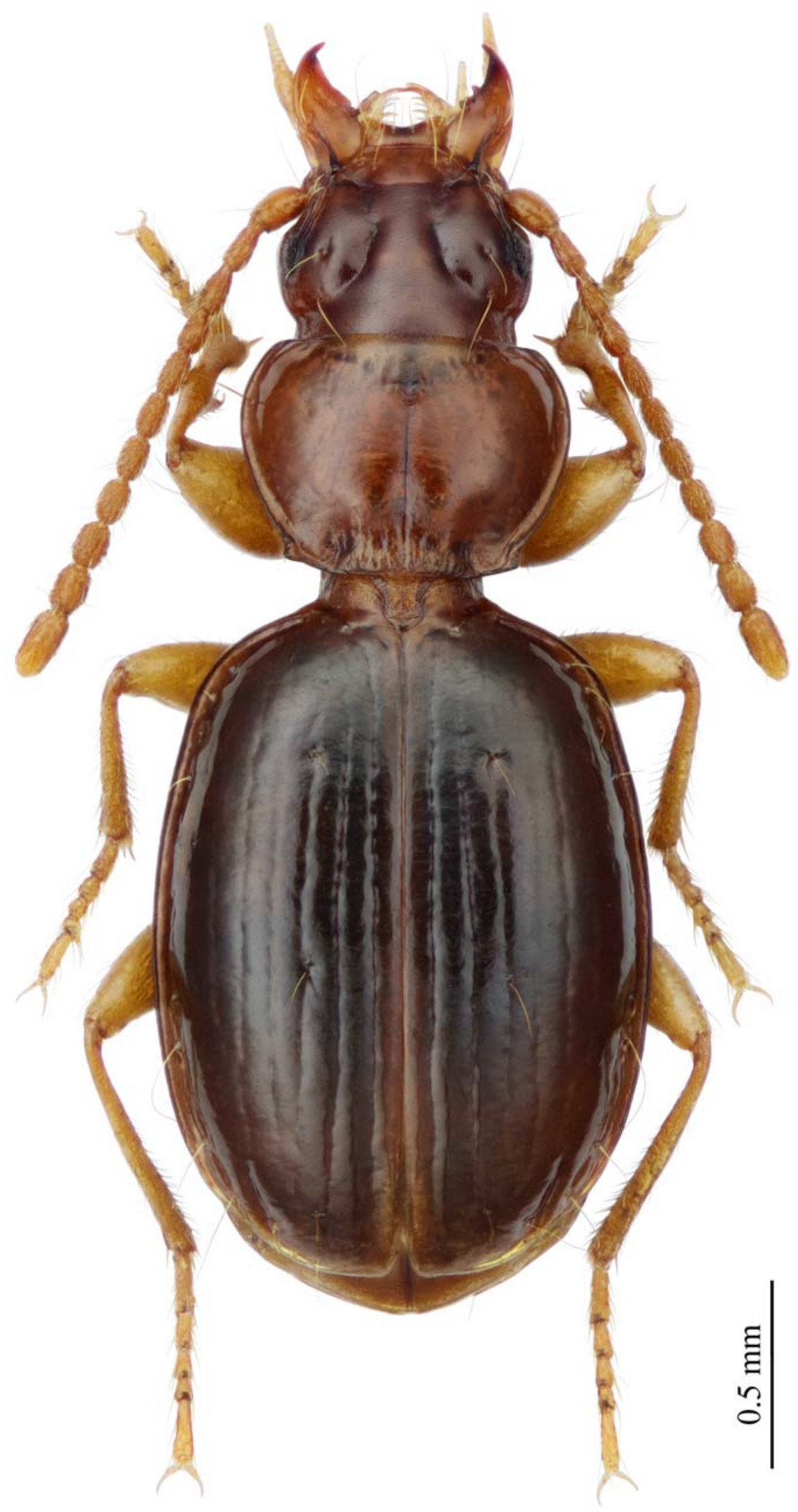

Fig. 8. Habitus of Trechus comma sp. n., OT, paratype.

Рис. 8. Общий вид Trechus comma sp. n., О7, паратип. 
pronotum distinctly rugose. Median line distinct, slightly impressed, deepest at level of prebasal transverse impression.

Elytra oval, with evenly arcuate sides, widest just after their mid-length. Humeri broadly rounded, prehumeral margin evenly arcuate, posthumeral sinuation indistinct. Elytral apex broadly rounded, nearly truncate, with a distinct preapical sinuation. Elytral striae rather deep and regular, even stria 7 partially visible. Intervals 3-4 subconvex, others flat, interval 2 distinctly wider than interval 1 in apical portion of elytra. All elytral striae finely punctured and slightly undulate. Stria 2 surpassing level of preapical pore, with or without distinct connection with stria 3, latter joining stria 4 at level clearly behind anterior termination of apical striole. Striae 5 and 6 joining each other slightly behind median group of umbilicate series or near that level; stria 7 without clear connection with any of other striae. Both parascutellar striole and parascutellar seta present. Apical recurrent striole of average length, deep and straight anteriorly, usually surpassing level of mid-distance between umbilicate pores 7 and 8 anteriad, joining fused stria $(5 \times 6)$ anteriorly. Striation on apical slope as follows: $((5 \times 6) \times A S)(3 \times 4)(2 \times 3)$. Apical triangle usually subequilateral, inner sides of apical triangles of both elytra subparallel to body axis. Preapical pore placed at level of umbilicate pore 8 or slightly behind. Angulo-apical pore usually set closer to exterior pore than to elytral suture. Lateral margins bordered and narrowly reflexed in posterior part while moderately reflexed in anterior part.

Protibiae depressed and slightly grooved on exterior surface in their median part; two basal segments of male protarsi dilated, markedly transverse.

Median lobe of aedeagus (Figs 5, 7) of medium size, rather thick, angularly curved at basal third, with ventral side nearly straight for most of its length, apical portion distinctly attenuates downwards and gradually narrowing toward small and button-like apex in lateral view. Apical lamella subparallel sided, with apical margin broadly rounded in dorsal view. Sagittal aileron small. Parameres of average size, their apex variable: rounded, oblique or truncate (Figs 5-6). Endophallus armature S-shaped in dorsal view and somewhat triangular shaped in lateral view; one poorly defined scaly area located near left dorsal wall of the median lobe.

SEXUAL DIMORPHISM. Males differ in larger body size (on average, $3.11 \mathrm{~mm}$ vs. $3.02 \mathrm{~mm}$ in females, $\mathrm{p} \leq 0.01$ ), proportionally longer elytra $(\mathrm{EL} / \mathrm{EW}$, on average, $1.34 \mathrm{vs}$. 1.31 in females, $p \leq 0.001 ; E L / P L$, on average, 2.77 vs. 2.73 in females, $\mathrm{p} \leq 0.05$; EL/TiL, on average, 2.39 vs. 2.36 in females, $\mathrm{p} \leq 0.05)$ and narrower pronotum $(\mathrm{PW} / \mathrm{PL}$, on average, 1.38 vs. 1.40 in females, $\mathrm{p} \leq 0.05$ ).

COMPARATIVE NOTES. T. comma sp.n. is most closely related to neighboring $T$. xiongmao sp.n. but differs in having larger size, flatter and longer eyes, less transverse pronotum with sides more deeply sinuate before larger hind angles, which are more produced, basal margin narrower, basal surface more coarsely rugose; elytra more elongate; apical recurrent striole longer, surpassing level of mid-distance between umbilicate pores 7 and 8; lateral margins of both pronotum and elytra less markedly reflexed (the differences in morphometric characters are shown in Table 2). The male genitalia of the new species differ from those of allied taxa in their rather thick shape (Fig. 5) and transverse triangular contour of the main copulatory piece in the endophallus armature (in lateral view). Nonetheless, the principal structure of the endophallus armature is similar to that of related species like T. xiongmao sp.n. (Fig. 5 vs. Fig. 2), T. gansuensis Deuve et Quéinnec, 1993, and T. xiei Deuve, 1992.
DISTRIBUTION. The species is known only from the upper valley of the Sanchagou River located north of the township of Tonghua, Wenchuan County, Sichuan.

BIONOMICS. The species occurs in the upper forest and subalpine zones, at elevations of 3600-3900 m. It was found mostly in the forest litter and along banks of mountain streams in the subalpine zone.

DERIVATIO NOMINIS. The species epithet derives from the particular shape of the copulatory piece resembling the comma.

\section{The validicollis-species group}

The group includes some species common in northern and central Sichuan. It can be characterized as follows: large-sized species, habitus robust and convex, color rufous to pitchy black, pronotum mostly with acute or rectangular hind angles and sides deeply sinuate before them, elytra broad ovate, with striae clearly impressed and roughly punctured. Preapical pore is mostly located closer to the elytral apex than level of anterior end of apical striole. The most important diagnostic feature of group members is the structure of the male genitalia: the median lobe large and thick, with apex curved upward; endophallus armature heavily sclerotized, consisting of several complexly twisted pieces.

The group is typical for Sichuan Province, only marginally penetrating to neighboring areas of Gansu Province (unpublished data).

Species are largely ripicolous and inhabit humid biotopes on banks of mountain streams. Despite their dark pigmentation, robust habitus and large size, members of this species group inhabit not only forests but also alpine meadows and often occur at very high elevations exceeding $4000 \mathrm{~m}$.

The group is named after the first species described, Trechus validicollis Sciaky et Pavesi, 1995 from the mountains near Sanggarpar. The group encompasses six known taxa (including the new species described below): T. validicollis. T. validicollis yakoushanus Deuve, 2004, T. altitudinum Deuve, 2004, T. kurbatovi Belousov et Kabak, 2000, T. trachypachys Sciaky et Pavesi, 1995. The latter species is known only from female specimens [Sciaky, Pavesi, 1995; Belousov, Kabak, 2000] and its assignment to this group needs further evidence.

\section{Trechus sharovae sp. n.}

Figs 9-13.

MATERIAL. Holotype $\sigma^{7}$, "China, NW Sichuan, NE of Lixian, N of Tonghua, basin of river near Pingshitou, $\mathrm{H} \sim 3300-3500 \mathrm{~m}, 19.08 .2002$, Belousov I. \& Kabak I. leg." [31 $41^{\circ} 49^{\prime \prime} \mathrm{N} / 103^{\circ} 23^{\prime} 11^{\prime \prime} \mathrm{E}-31^{\circ} 44^{\prime} 15^{\prime \prime} \mathrm{N}$ / 103'22'54"N]. Paratypes: 13(4) $0^{7} 0^{7}, 5$ 오, collected with holotype (IZAS, NME, MPU, ZSM, CAG, CAK, CBK, CJS); 3(3) $\mathrm{O}^{7} \sigma^{7}$, "CH, NW Sichuan, NE of Lixian, N Tonghua, basin of river near Pingshitou, S of Shibanpengzi, H 3600-3900 m, 20.08.2002, Belousov I. \& Kabak I. leg." [31 $44^{\prime} 30^{\prime \prime} \mathrm{N} / 103^{\circ} 22^{\prime} 50^{\prime \prime} \mathrm{E}-31^{\circ} 44^{\prime} 41^{\prime \prime} \mathrm{N} /$ $\left.103^{\circ} 22^{\prime} 50^{\prime} \mathrm{E}\right]$ (CBK); 1(1) $0^{7}$, “CH, NW Sichuan, NE of Lixian, N Tonghua, basin of river near Pingshitou, S of Shibanpengzi, H 3900 m, 22.08.2002, Belousov I. \& Kabak I. leg." [31 $44^{\prime} 41^{\prime \prime N}$ / $103^{\circ} 22^{\prime} 49^{\prime \prime} \mathrm{E}$, corrected height $\left.=3600 \mathrm{~m}\right](\mathrm{CBK})$.

DESCRIPTION. Medium-sized species, body length usually slightly less than $4 \mathrm{~mm}$, habitus robust and subparallel sided, dorsum moderately convex (Fig. 9). Legs and antennae rather slender; middle antennomeres much longer than wide. Color of upper side rather concolorous, reddish brown, usually with darker hind part of head and disk of elytra; the suture and margins of the latter normally slightly paler, amber reddish. Legs pale amber reddish, antennae vaguely obscured from segments $3-4$. 


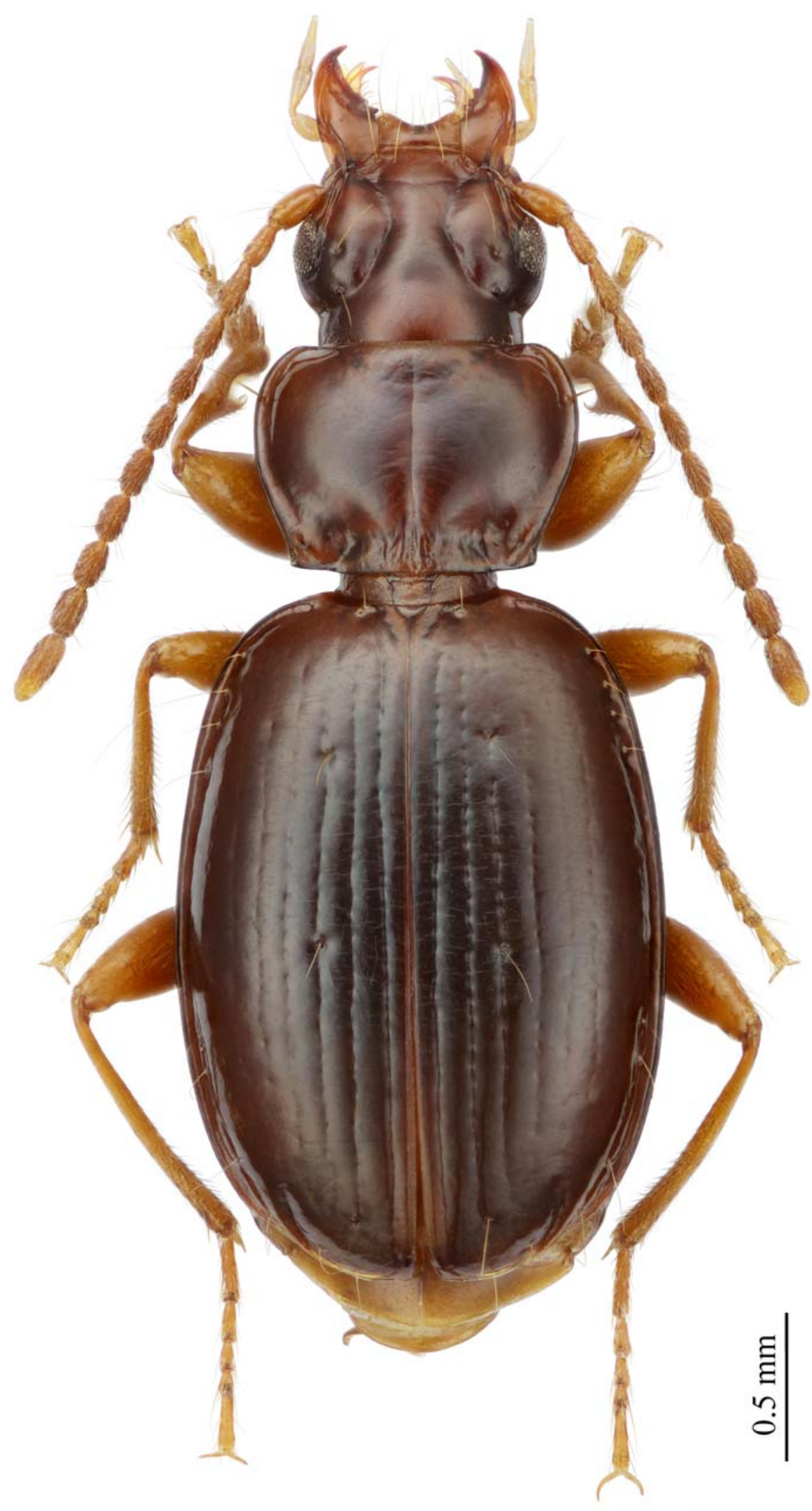

Fig. 9. Habitus of Trechus sharovae sp. n., $\sigma^{7}$, paratype.

Рис. 9. Общий вид Trechus sharovae sp. n., о7, паратип. 
Microsculpture well distinguished, consisting of isodiametric meshes on head, very transverse meshes on pronotum, and transverse lines on elytra. Pronotum with slight, elytra with distinct iridescence. Micropunctures well developed on the whole upper surface.

Head of medium size. Frontal furrows well impressed, angularly curved in their anterior third. Parietal impression indistinct. Supraorbital setiferous pores located in lines subparallel to body axis; posterior pore more deeply foveolate, located at level clearly behind posterior edge of eye. Eyes medium-sized, evenly convex; tempora rather long, slightly convex, glabrous. Mandibles stout, evenly curved on their exterior margin. Tooth on right mandible tridentate, its shape rather variable but distal denticle always most prominent and more isolated from other denticles. Labrum with anterior margin concave.

Pronotum moderately transverse, subconvex on disk, with maximum width clearly before its mid-length, marginally wider at base than at apex. Sides slightly to moderately sinuate before hind angles. Latter medium-sized, subrectangular, pointed apically. Basal margin nearly straight, barely emarginate on sides. Anterior margin rectilinear to slightly concave; front angles rounded and barely salient. Prebasal transverse impression moderately impressed, located far from and subparallel to basal margin, sharply curved in basal foveae. The latter large and deep, often with a triangular impression in bottom. Basal surface longitudinally rugose. Preapical transverse impression vague and shallow, more distinct laterally, often with a few coarse punctures or impressions medially. Lateral groove rather wide, narrowed to front angles and dilated to pronotal base. Median line distinct, more deeply impressed toward base, shortened anteriorly, reaching basal margin of pronotum. Discal foveae shallow or indistinct.

Elytra ovate, subconvex, with maximum width near their mid-length, relatively narrow (as compared to other members of the group), elytra commonly rounded at apex. Humeri rounded. Preapical sinuation distinct. Two discal setiferous pores in stria 3. Preapical pore located in the apical cross, much closer to stria 2 than to stria 3 , at level markedly behind anterior termination of apical striole. Apical triangle slightly elongate, its inner side normally slightly divergent posteriad or parallel to elytral suture. Angulo-apical pore approximately in middle between exterior pore and elytral suture. Umbilicate pores well aggregated, umbilicate pores 7 and 8 most spaced (compared to those within other groups). Elytral striae 1-5 well impressed and distinct for most of their length, though becoming increasingly shallower toward sides; all striae coarsely punctured. Stria 6 very shallow, even in its median part, stria 7 only partially discernible. Inner interspaces slightly convex, others flat. Striation on apical slope

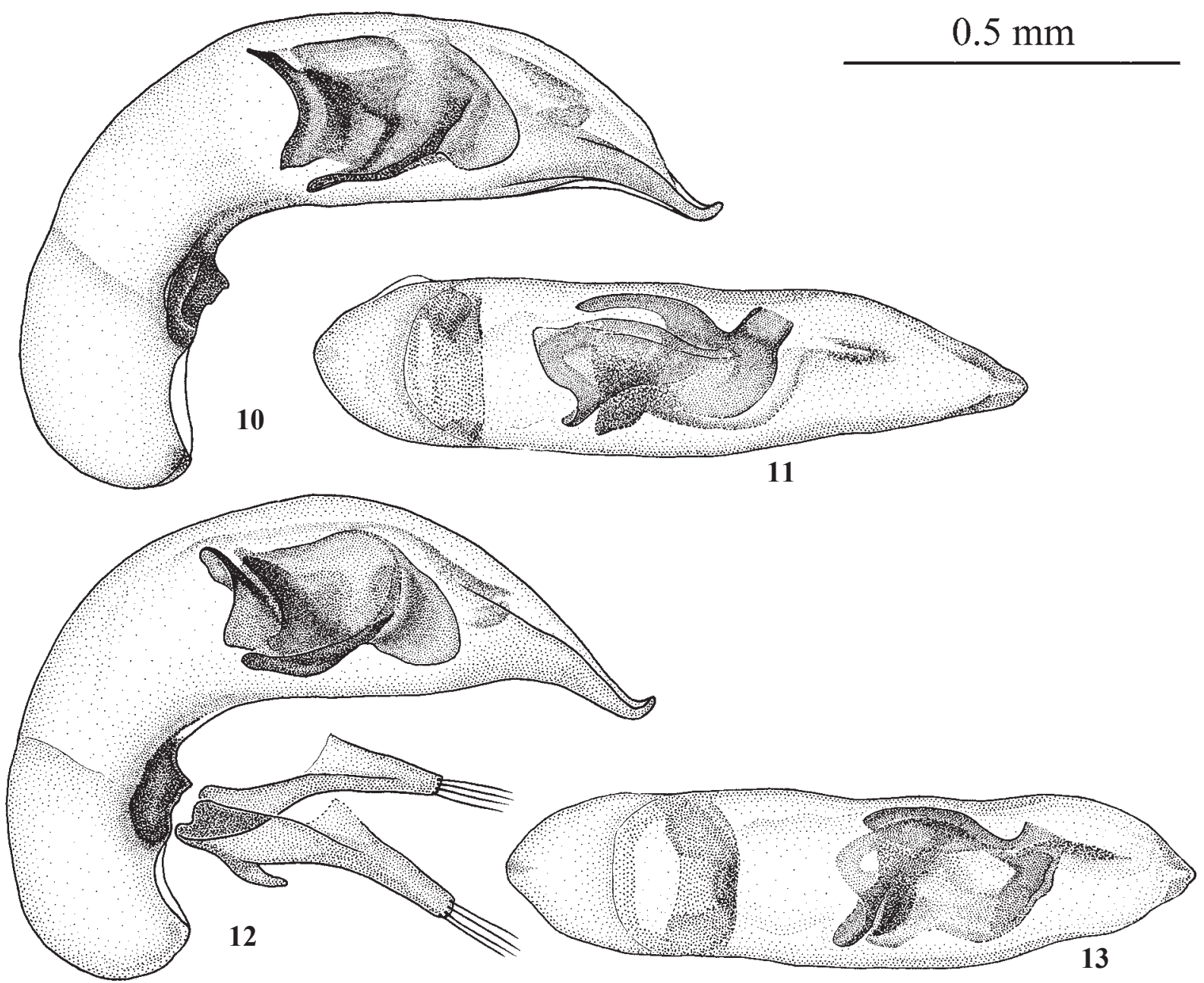

Figs 10-13. Male genitalia of Trechus sharovae sp. n., paratypes: 10,12 - lateral view; 11, 13 - dorsal view. Рис. 10-13. Гениталии самцов Trechus sharovae sp. n., паратипы: 10, 12 - сбоку; 11, 13 - сверху. 
rather shallow: striae 3 and 4 joining each other at level between anterior termination of apical striole and preapical pore, striae 5 and 6 either independently directed to apical striole or disappearing posteriorly without clear connection. Striation on apical slope, although rather shallow, especially striae 5 and 6 , could be summarized as follows: $(5 \times A S \mid 5 \times 6 \times A S)(3 \times 4)(2 \times 3)$. Parascutellar pore present, parascutellar striole well developed, rather long. Apical striole sharply engraved; rather straight, directed to the site of stria 5 anteriorly and abruptly interrupted there. Lateral groove narrower than average for the group, but wider than in most other groups of the genus, margins slightly and evenly reflexed throughout. Lateral border with a distinct hook anteriorly.

Protibiae thick, especially in apical half, barely grooved on exterior face in distal third, their anterior surface glabrous except for its innermost apex bearing a few rudimentary hairs. Metatibiae slender, nearly straight, moderately thickened distally. Male protarsi with two basal segments markedly dilated and inwardly dentate; both segments 1 and 2 transverse.
Aedeagus relatively large (compared to body size) and thick, markedly curved at basal portion, rather bulky in middle portion (Figs 10-13). Apical portion attenuating downward, ending with a well-developed and oblique button, adjacent portion of ventral margin markedly sinuate. Sagittal aileron missing; basal orifice slightly concave. Endophallus armature consisting of two large and heavily sclerotized sclerites typical for members of the group but their shape and position deviate compared to other species: distal margin of longer sclerite semicircular, its proximal portion markedly concave. Parameres of medium length, each bearing 4-5 apical setae; left paramere longer, with a ventral apophysis.

SEXUAL DIMORPHISM. Males differ in larger body size (on average, $3.12 \mathrm{~mm}$ vs. $2.99 \mathrm{~mm}$ in females, $\mathrm{p} \leq 0.01$ ) and proportionally longer elytra $(\mathrm{EL} / \mathrm{EW}$, on average, 1.35 vs. 1.33 in females, $\mathrm{p} \leq 0.05)$ and longer antennae (EL/AL, on average, 1.18 vs. 1.20 in females, $p \leq 0.05$ ).

COMPARATIVE NOTES. Externally, the species is similar to other members of the group, especially to smaller

Table 1. Morphometric characters of Trechus species. Abbeviations are as indicated in Material and Methods. Таблица 1. Морфометрические признаки видов рода Trechus. Сокращения указаны в разделе «Материал и методы».

\begin{tabular}{|c|c|c|c|c|c|c|c|}
\hline \multirow[b]{2}{*}{ Indices } & \multicolumn{3}{|c|}{ Range (average), $N$} & \multirow[b]{2}{*}{ Indices } & \multicolumn{3}{|c|}{ Range (average), $N$} \\
\hline & $\begin{array}{c}\text { xiong- } \\
\text { mao }\end{array}$ & comma & sharovae & & $\begin{array}{c}\text { xiong- } \\
\text { mao }\end{array}$ & comma & sharovae \\
\hline Length, mm & $\begin{array}{l}2.72-3.15 \\
(2.93), 21\end{array}$ & $\begin{array}{l}2.90-3.25 \\
(3.07), 34\end{array}$ & $\begin{array}{l}3.56-4.05 \\
(3.82), 19\end{array}$ & $\mathrm{EL} / \mathrm{EW}$ & $\begin{array}{l}1.24-1.36 \\
(1.30), 20\end{array}$ & $\begin{array}{l}1.29-1.37 \\
(1.32), 34\end{array}$ & $\begin{array}{l}1.35-1.41 \\
(1.38), 19\end{array}$ \\
\hline $\mathrm{EL} / \mathrm{BH}$ & $\begin{array}{l}2.08-2.44 \\
(2.24), 13\end{array}$ & $\begin{array}{l}2.22-2.52 \\
(2.32), 19\end{array}$ & $\begin{array}{l}2.38-2.76 \\
(2.50), 11\end{array}$ & $\mathrm{EW} / \mathrm{PW}$ & $\begin{array}{l}1.44-1.56 \\
(1.49), 20\end{array}$ & $\begin{array}{l}1.45-1.55 \\
(1.50), 34\end{array}$ & $\begin{array}{l}1.41-1.50 \\
(1.45), 19\end{array}$ \\
\hline $\mathrm{PW} / \mathrm{HW}$ & $\begin{array}{l}1.26-1.34 \\
(1.30), 21\end{array}$ & $\begin{array}{l}1.25-1.32 \\
(1.29), 34\end{array}$ & $\begin{array}{l}1.25-1.34 \\
(1.31), 19\end{array}$ & $\mathrm{EL} / \mathrm{PL}$ & $\begin{array}{l}2.61-2.90 \\
(2.74), 21\end{array}$ & $\begin{array}{l}2.62-2.91 \\
(2.76), 34\end{array}$ & $\begin{array}{l}2.69-2.98 \\
(2.83), 19\end{array}$ \\
\hline $\mathrm{EW} / \mathrm{HW}$ & $\begin{array}{l}1.84-2.04 \\
(1.94), 20\end{array}$ & $\begin{array}{l}1.84-2.02 \\
(1.93), 34\end{array}$ & $\begin{array}{l}1.85-2.00 \\
(1.91), 19\end{array}$ & $\mathrm{D} 1, \%$ & $\begin{array}{l}17.9-22.7 \\
(19.8), 21\end{array}$ & $\begin{array}{l}17.1-23.6 \\
(20.2), 34\end{array}$ & $\begin{array}{l}18.1-23.5 \\
(20.7), 19\end{array}$ \\
\hline YL/TL & $\begin{array}{l}1.13-1.47 \\
(1.29), 21\end{array}$ & $\begin{array}{l}1.35-1.80 \\
(1.48), 34\end{array}$ & $\begin{array}{l}1.48-2.14 \\
(1.79), 19\end{array}$ & $\mathrm{D} 2, \%$ & $\begin{array}{l}46.5-53.9 \\
(50.1), 21\end{array}$ & $\begin{array}{l}45.5-54.7 \\
(50.1), 34\end{array}$ & $\begin{array}{l}45.1-56.0 \\
(51.0), 19\end{array}$ \\
\hline YL/L3 & $\begin{array}{l}0.96-1.25 \\
(1.07), 21\end{array}$ & $\begin{array}{l}1.05-1.27 \\
(1.18), 34\end{array}$ & $\begin{array}{l}1.08-1.31 \\
(1.19), 19\end{array}$ & $\mathrm{DP}, \%$ & $\begin{array}{l}84.4-91.5 \\
(87.0), 21\end{array}$ & $\begin{array}{l}85.9-91.8 \\
(89.6), 34\end{array}$ & $\begin{array}{l}88.8-93.5 \\
(91.1), 19\end{array}$ \\
\hline L3/YL & $\begin{array}{l}0.80-1.05 \\
(0.94), 21\end{array}$ & $\begin{array}{l}0.79-0.95 \\
(0.85), 34\end{array}$ & $\begin{array}{l}0.76-0.93 \\
(0.84), 19\end{array}$ & $\mathrm{U} 1, \%$ & $\begin{array}{l}6.54-8.62 \\
(7.80), 21\end{array}$ & $\begin{array}{l}6.49-8.87 \\
(7.64), 34\end{array}$ & $\begin{array}{l}5.45-8.08 \\
(7.10), 19\end{array}$ \\
\hline $\mathrm{L} 3 / \mathrm{W} 3$ & $\begin{array}{l}1.80-2.33 \\
(2.06), 21\end{array}$ & $\begin{array}{l}1.71-2.00 \\
(1.90), 34\end{array}$ & $\begin{array}{l}2.05-2.36 \\
(2.19), 19\end{array}$ & $\mathrm{U} 2, \%$ & $\begin{array}{l}10.7-13.9 \\
(12.4), 21\end{array}$ & $\begin{array}{l}10.9-14.1 \\
(12.4), 34\end{array}$ & $\begin{array}{l}9.70-13.8 \\
(12.3), 19\end{array}$ \\
\hline $\mathrm{L} 3 / \mathrm{L} 2$ & $\begin{array}{l}1.04-1.23 \\
(1.12), 21\end{array}$ & $\begin{array}{l}1.03-1.20 \\
(1.10), 34\end{array}$ & $\begin{array}{l}1.10-1.27 \\
(1.18), 19\end{array}$ & U3, \% & $\begin{array}{l}16.7-20.9 \\
(18.2), 21\end{array}$ & $\begin{array}{l}16.0-18.9 \\
(17.4), 33\end{array}$ & $\begin{array}{l}14.5-18.8 \\
(16.8), 19\end{array}$ \\
\hline $\mathrm{EL} / \mathrm{AL}$ & $\begin{array}{l}1.08-1.20 \\
(1.13), 21\end{array}$ & $\begin{array}{l}1.10-1.20 \\
(1.15), 34\end{array}$ & $\begin{array}{l}1.04-1.12 \\
(1.08), 19\end{array}$ & $\mathrm{U} 4, \%$ & $\begin{array}{l}23.0-27.5 \\
(24.9), 21\end{array}$ & $\begin{array}{l}21.3-26.3 \\
(23.9), 33\end{array}$ & $\begin{array}{l}21.2-25.5 \\
(23.4), 19\end{array}$ \\
\hline $\mathrm{AL} / \mathrm{EL}$ & $\begin{array}{l}0.83-0.92 \\
(0.88), 21\end{array}$ & $\begin{array}{l}0.83-0.91 \\
(0.87), 34\end{array}$ & $\begin{array}{l}0.89-0.96 \\
(0.93), 19\end{array}$ & $\mathrm{U} 5, \%$ & $\begin{array}{l}51.2-57.9 \\
(54.8), 21\end{array}$ & $\begin{array}{l}53.4-59.2 \\
(56.9), 34\end{array}$ & $\begin{array}{l}59.5-63.4 \\
(61.7), 19\end{array}$ \\
\hline $\mathrm{PW} / \mathrm{PL}$ & $\begin{array}{l}1.38-1.50 \\
(1.42), 21\end{array}$ & $\begin{array}{l}1.34-1.44 \\
(1.39), 34\end{array}$ & $\begin{array}{l}1.37-1.47 \\
(1.41), 19\end{array}$ & U6, \% & $\begin{array}{l}59.0-65.5 \\
(62.3), 21\end{array}$ & $\begin{array}{l}61.1-67.2 \\
(64.3), 34\end{array}$ & $\begin{array}{l}64.9-69.2 \\
(67.5), 19\end{array}$ \\
\hline $\mathrm{PW} / \mathrm{PB}$ & $\begin{array}{l}1.29-1.43 \\
(1.37), 21\end{array}$ & $\begin{array}{l}1.37-1.47 \\
(1.41), 34\end{array}$ & $\begin{array}{l}1.31-1.42 \\
(1.34), 19\end{array}$ & $\mathrm{U} 7, \%$ & $\begin{array}{l}76.1-81.0 \\
(78.4), 21\end{array}$ & $\begin{array}{l}76.6-81.9 \\
(79.1), 34\end{array}$ & $\begin{array}{l}80.3-84.4 \\
(82.7), 19\end{array}$ \\
\hline $\mathrm{PA} / \mathrm{PB}$ & $\begin{array}{l}0.96-1.07 \\
(1.01), 21\end{array}$ & $\begin{array}{l}1.01-1.08 \\
(1.04), 34\end{array}$ & $\begin{array}{l}0.92-1.00 \\
(0.96), 19\end{array}$ & U8, \% & $\begin{array}{l}84.5-89.8 \\
(87.2), 21\end{array}$ & $\begin{array}{l}85.9-89.9 \\
(87.9), 34\end{array}$ & $\begin{array}{l}87.5-90.6 \\
(89.5), 19\end{array}$ \\
\hline PB/PA & $\begin{array}{l}0.93-1.04 \\
(0.99), 21\end{array}$ & $\begin{array}{l}0.92-0.99 \\
(0.96), 34\end{array}$ & $\begin{array}{l}1.00-1.09 \\
(1.04), 19\end{array}$ & $\mathrm{EL} / \mathrm{TiL}$ & $\begin{array}{l}2.17-2.49 \\
(2.32), 19\end{array}$ & $\begin{array}{l}2.29-2.44 \\
(2.38), 34\end{array}$ & $\begin{array}{l}2.22-2.32 \\
(2.27), 14\end{array}$ \\
\hline $\mathrm{PSa}, \%$ & $\begin{array}{l}25.0-32.1 \\
(27.9), 21\end{array}$ & $\begin{array}{l}21.3-30.7 \\
(25.7), 34\end{array}$ & $\begin{array}{l}23.2-29.1 \\
(26.3), 19\end{array}$ & TiL/TaL & $\begin{array}{l}1.20-1.40 \\
(1.31), 19\end{array}$ & $\begin{array}{l}1.20-1.33 \\
(1.27), 34\end{array}$ & $\begin{array}{l}1.23-1.35 \\
(1.29), 14\end{array}$ \\
\hline
\end{tabular}


species like T. trachypachys Sciaky et Pavesi, 1995, T. altitudinum Deuve, 2004, and T. kurbatovi Belousov et Kabak, 2000. From the former species which is known only from female specimens, it differs mostly in paler coloration and shape of pronotum with basal margin less oblique at sides and lateral margins less sinuate before hind angles. On the other hand, the membership of T. trachypachys in the validicollis species group, as it was noted earlier, needs to be confirmed, see also [Belousov, Kabak, 2000]. Among species with known males, T. altitudinum seems to be most similar to $T$. sharovae sp.n. Their closeness is also consistent with their neighboring distribution (approximately $100 \mathrm{~km}$ between the type localities). Both species share roughly the same coloration, habitus and very similar structure of the male genitalia: median lobe rather short and stout, with short apex and large endophallus armature filling up nearly all the lumen of the median lobe. However, $T$. sharovae sp.n. differs in having the median lobe with slenderer apical portion, deeper sinuation of ventral margin before apex and more developed button-like apex; endophallus armature readily differs in the main copulatory piece with distal portion much narrowly rounded vs. broad and subangular in T. altitudinum. T. sharovae sp.n. is also similar to T. kurbatovi. Externally, it differs from the latter species mainly in the structure of pronotum with hind angles which are smaller and less acute. The structure of the male genitalia is significantly different: median lobe more robust, ventral margin of apical portion much deeper emarginate, and the main copulatory piece more developed and complexly twisted, less elongate, with apical portion much more broadly arcuate (vs. falcate in kurbatovi) and apical lamella more acute (broadly rounded in kurbatovi) in dorsal view.

DISTRIBUTION. The species is known only from the upper valley of the Sanchagou River located north of the township of Tonghua, Li County, Sichuan.

BIONOMICS. The species was found in the forest zone at elevations from 3300 to $3900 \mathrm{~m}$.

Table 2. Statistically significant differences between Trechus species (Mann-Whitney criterion, both sexes). Abbeviations are as indicated in Material and Methods.

Таблица 2. Статистически значимые различия между видами рода Trechus (U-критерий Манна-Уитни, оба пола). Сокращения указаны в разделе «Материал и методы»

\begin{tabular}{|c|c|c|c|c|c|}
\hline Indices & $\boldsymbol{P}$ & Range (average) sp. 1 & $N$ sp. 1 & Range (average) sp. 2 & $N$ sp. 2 \\
\hline \multicolumn{6}{|c|}{ T. xiongmao vs. T. xiei } \\
\hline $\mathrm{PA} / \mathrm{PB}$ & 0.001 & $0.96-1.07(1.01)$ & 21 & $0.96-1.10(1.05)$ & 53 \\
\hline $\mathrm{U} 5, \%$ & 0.001 & $51.23-57.87(54.76)$ & 21 & $52.83-60.45(57.36)$ & 53 \\
\hline YL/L3 & 0.001 & $0.96-1.25(1.07)$ & 21 & $1.08-1.40(1.21)$ & 53 \\
\hline $\mathrm{U} 2, \%$ & 0.01 & $10.68-13.93(12.39)$ & 21 & $11.25-15.49(13.47)$ & 53 \\
\hline $\mathrm{PW} / \mathrm{PB}$ & 0.01 & $1.29-1.43(1.37)$ & 21 & $1.30-1.48(1.41)$ & 53 \\
\hline EL/TiL & 0.05 & $2.17-2.49(2.32)$ & 19 & $2.30-2.54(2.42)$ & 51 \\
\hline YL/TL & 0.05 & $1.13-1.47(1.29)$ & 21 & $1.14-1.64(1.38)$ & 53 \\
\hline U6, \% & 0.05 & $59.02-65.53(62.28)$ & 21 & $60.95-67.54(64.04)$ & 53 \\
\hline EL/AL & 0.05 & $1.08-1.20(1.13)$ & 21 & $1.09-1.21(1.15)$ & 52 \\
\hline \multicolumn{6}{|c|}{ T. xiongmao vs. T. gansuensis } \\
\hline $\mathrm{EL} / \mathrm{AL}$ & 0.001 & $1.08-1.20(1.13)$ & 21 & $1.13-1.26(1.19)$ & 75 \\
\hline YL/TL & 0.001 & $1.13-1.47(1.29)$ & 21 & $1.35-2.13(1.68)$ & 75 \\
\hline YL/L3 & 0.001 & $0.96-1.25(1.07)$ & 21 & $1.10-1.44(1.23)$ & 75 \\
\hline DP, $\%$ & 0.01 & $84.43-91.45(87.00)$ & 21 & $85.95-93.69(89.83)$ & 75 \\
\hline EW/PW & 0.01 & $1.44-1.56(1.49)$ & 20 & $1.45-1.63(1.54)$ & 75 \\
\hline EL/EW & 0.05 & $1.24-1.36(1.30)$ & 20 & $1.28-1.42(1.34)$ & 75 \\
\hline \multicolumn{6}{|c|}{ T. comma vs. T. xiongmao } \\
\hline Length, $\mathrm{mm}$ & 0.001 & $2.90-3.25(3.07)$ & 34 & $2.72-3.15(2.93)$ & 21 \\
\hline $\mathrm{PW} / \mathrm{PL}$ & 0.001 & $1.34-1.44(1.39)$ & 34 & $1.38-1.50(1.42)$ & 21 \\
\hline $\mathrm{PW} / \mathrm{PB}$ & 0.001 & $1.37-1.47(1.41)$ & 34 & $1.29-1.43(1.37)$ & 21 \\
\hline YL/TL & 0.001 & $1.35-1.80(1.48)$ & 34 & $1.13-1.47(1.29)$ & 21 \\
\hline YL/L3 & 0.001 & $1.05-1.27(1.18)$ & 34 & $0.96-1.25(1.07)$ & 21 \\
\hline L3/W3 & 0.001 & $1.71-2.00(1.90)$ & 34 & $1.80-2.33(2.06)$ & 21 \\
\hline $\mathrm{PA} / \mathrm{PB}$ & 0.001 & $1.01-1.08(1.04)$ & 34 & $0.96-1.07(1.01)$ & 21 \\
\hline $\mathrm{PSa}, \%$ & 0.001 & $21.28-30.68(25.70)$ & 34 & $25.00-32.09(27.86)$ & 21 \\
\hline $\mathrm{DP}, \%$ & 0.001 & $85.94-91.83(89.62)$ & 34 & $84.43-91.45(87.00)$ & 21 \\
\hline $\mathrm{U} 5, \%$ & 0.001 & $53.41-59.22(56.88)$ & 34 & $51.23-57.87(54.76)$ & 21 \\
\hline $\mathrm{U} 6, \%$ & 0.001 & $61.11-67.23(64.31)$ & 34 & $59.02-65.53(62.28)$ & 21 \\
\hline $\mathrm{EL} / \mathrm{EW}$ & 0.01 & $1.29-1.37(1.32)$ & 34 & $1.24-1.36(1.30)$ & 20 \\
\hline $\mathrm{EL} / \mathrm{AL}$ & 0.05 & $1.10-1.20(1.15)$ & 34 & $1.08-1.20(1.13)$ & 21 \\
\hline $\mathrm{U} 8, \%$ & 0.05 & $85.94-89.92(87.89)$ & 34 & $84.45-89.77(87.15)$ & 21 \\
\hline
\end{tabular}


DERIVATIO NOMINIS. We are honored to name this species in the memory of the late professor Inessa Khristianovna Sharova for her invaluable contribution to our knowledge of carabid beetles.

Acknowledgments. We are very grateful to Drs. S.-I. Uéno (Tokyo), Yu. Imura (Yokohama), A. Konstantinov (Washington), B. Březina (Prague) and A. Gitzen (Neuhofen) for their help in our research projects on Chinese Trechini during different periods of time. We also thank Dr. A.E. Korolev (Saint-Petersburg) for his help in mounting specimens of the new Trechus species collected in China.

Competing interests. The authors declare no competing interests.

\section{References}

Belousov I.A., Kabak I.I. 1996. To the knowledge of the Asiatic species of the genus Trechus Clairville (Insecta: Coleoptera: Carabidae) // Annalen des Naturhistorischen Museums in Wien. Bd.98B. S.361-398.

Belousov I.A., Kabak I.I. 2000. [Contribution to the knowledge of species of the genus Trechus Clairv. (Coleoptera, Carabidae) from China] // Entomologicheskoe Obozrenie. Vol.79. No.1. P.49-78 [in Russian, with English summary].

Belousov I.A., Kabak I.I. 2001. New Duvalius and Trechus species from China (Coleoptera: Carabidae: Trechini) // Folia Heyrovskyana. Vol.9. P.1-33

Belousov I.A., Kabak I.I. 2003. New Trechini from China (Coleoptera, Carabidae) (Coleoptera, Carabidae) // TETHYS Entomological Research. Vol.8. P.15-86.

Belousov I.A., Kabak I.I. 2014. A taxonomic review of the genus Junnanotrechus Uéno \& Yin, 1993 (Coleoptera: Carabidae:
Trechinae), with description of six new species // Zootaxa. Vol.3811. No.4. P.401-437. http://dx.doi.org/10.11646/zootaxa.3811.4.1.

Belousov I.A., Kabak I.I. 2019a. New species of the genus Trechus Clairville, 1806 from the Chinese Tien Shan (Coleoptera: Carabidae) // Zootaxa. Vol.4679. No.1. P.47-68. https://doi.org/ 10.11646/zootaxa.4679.1.3.

Belousov I.A., Kabak I.I. 2019b. Two New Species of the Genus Trechus Clairville, 1806 from Gansu Province of China (Coleoptera, Carabidae) // Entomological Review. Vol.99. No.7. P.906-913

Belousov I.A., Kabak I.I. 2020. New Trechus species of the kozlovi group from Sichuan (Coleoptera: Carabidae) // Zootaxa. Vol.4786. No.4. P.451-484. https://doi.org/10.11646/zootaxa.4786.4.1.

Deuve T. 1992. Contribution à la connaissance des Trechidae asiatiques (Coleoptera) // Bulleten de la Société entomologique de France. Vol.97. P.171-184.

Deuve T. 2004. Nouveaux Trechidae (Trechinae et Bembidiinae) d'Afrique et d'Asie (Coleoptera, Caraboidea) // Coléoptères. Vol.10. No.19. P.215-234.

Deuve T. 2009. Nouveaux Leistus, Trechus et Lissopogonus d'Asie (Coleoptera, Caraboidea) // Revue Française d'Entomologie (N.S.). Vol.31. P.81-91.

Deuve Th., Kavanaugh D.H., Liang H.-B. 2015. Trois Trechini nouveaux du Mont Laojun, près de Lijiang, dans le Yunnan, Chine // Coléoptères. Vol.21. No.15. P.171-178.

Deuve T., Quéinnec E. 1993. Nouveaux Trechus du Qinghai, du Sichuan et du Gansu, Chine (Coleoptera, Caraboidea: Trechidae) // Opuscula Zoologica Fluminensia. Vol.104. P.1-9.

Sciaky R., Pavesi M. 1995. Nuove specie di Trechus del Sichuan (Cina) (Coleoptera, Carabidae)// Acta coleopterologica. Vol.11. P.23-32.

Schmidt J. 2009. Taxonomic and biogeographical review of the genus Trechus Clairville, 1806, from the Tibetan Himalaya and the southern central Tibetan Plateau (Coleoptera: Carabidae: Trechini) // Zootaxa. Vol.2178. P.1-72. 